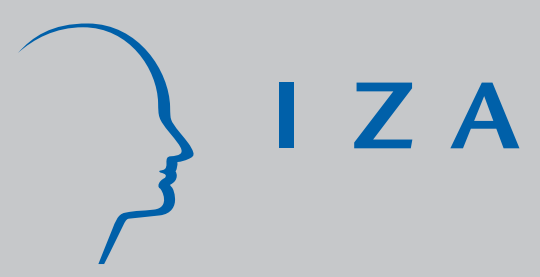

IZA DP No. 3801

Intergenerational Top Income Mobility in Sweden: A Combination of Equal Opportunity and Capitalistic Dynasties

Anders Björklund

J esper Roine

Daniel Waldenström

October 2008 


\title{
Intergenerational Top Income Mobility in Sweden: A Combination of Equal Opportunity and Capitalistic Dynasties
}

\author{
Anders Björklund \\ SOFI, Stockholm University \\ and IZA
}

Jesper Roine

SITE, Stockholm School of Economics

Daniel Waldenström

Research Institute of Industrial Economics (IFN)

\author{
Discussion Paper No. 3801 \\ October 2008
}

\author{
IZA \\ P.O. Box 7240 \\ 53072 Bonn \\ Germany \\ Phone: +49-228-3894-0 \\ Fax: +49-228-3894-180 \\ E-mail: iza@iza.org
}

\begin{abstract}
Any opinions expressed here are those of the author(s) and not those of IZA. Research published in this series may include views on policy, but the institute itself takes no institutional policy positions.

The Institute for the Study of Labor (IZA) in Bonn is a local and virtual international research center and a place of communication between science, politics and business. IZA is an independent nonprofit organization supported by Deutsche Post World Net. The center is associated with the University of Bonn and offers a stimulating research environment through its international network, workshops and conferences, data service, project support, research visits and doctoral program. IZA engages in (i) original and internationally competitive research in all fields of labor economics, (ii) development of policy concepts, and (iii) dissemination of research results and concepts to the interested public.
\end{abstract}

IZA Discussion Papers often represent preliminary work and are circulated to encourage discussion. Citation of such a paper should account for its provisional character. A revised version may be available directly from the author. 


\begin{abstract}
Intergenerational Top Income Mobility in Sweden: A Combination of Equal Opportunity and Capitalistic Dynasties*

This paper presents new evidence on intergenerational income and earnings mobility in the top of the distributions. Using a large dataset of matched father-son pairs in Sweden we are able to obtain results for fractions as small as 0.1 percent of the population. Overall, mobility is lower for incomes than for earnings and it appears to decrease the higher up in the distribution one goes. In the case of incomes, however, we find that mobility decreases dramatically within the top percentile of the population. Our results suggest that Sweden, well-known for its egalitarian achievements, is a society where equality of opportunity for a large majority of wage earners coexists with capitalistic dynasties.
\end{abstract}

JEL Classification: D31, J62

Keywords: intergenerational income mobility, top incomes, earnings inequality, income inequality, welfare state, non-linear regression, quantile regression

Corresponding author:

Anders Björklund

Swedish Institute for Social Research

Stockholm University

SE-10691 Stockholm

Sweden

E-mail: anders@sofi.su.se

\footnotetext{
* We are grateful to Robert Erikson, Markus Jäntti, Thomas Piketty, Tim Smeeding and seminar participants at SOFI, Stockholm University and Université Libre de Bruxelles for constructive comments. Björklund acknowledges research funding from Swedish Council for Working Life and Social Research (FAS) and Waldenström acknowledges financial support from the Jan Wallander and Tom Hedelius Foundation and the Gustaf Douglas Research Program on entrepreneurship at IFN.
} 
"Who cares if the boss earns 300 times more than the average working stiff, if the stiff knows he can become the boss?”

The Economist, June 15th, 2006

"Our finance minister is the enemy of the millionaire and a friend of the multimillionaire.”

Anonymous Swedish economist on the Swedish tax system in the early 1970s (Sandford 1971, p. 152)

\section{Introduction}

This paper studies intergenerational income mobility focusing on top income earners in Sweden. More precisely, we study the income association of matched father-son pairs, where the sons are a representative sample of all men born in 1960-1967. The fact that our sample consists of more than 100,000 pairs (35 percent of the whole population) means that we are able to get good precision estimates for fractions as small as the top 0.1 percent of the income distribution.

There are two main motivations for this study. The first is based on the growing literature on top income shares over the long run. ${ }^{1}$ While initially driven by a lack of comparable long-run series of inequality, this literature has also shown the importance of studying the top in more detail in order to understand changes in overall inequality. ${ }^{2}$ In particular, it has been shown that the recent surge in inequality in many countries has been driven mainly by large income increases in the top percent (or even smaller fractions). However, so far this literature has not been able to answer questions about mobility. Mobility is just as crucial for evaluating the increase in top income inequality as it is for inequality in general. Indeed, when asked about the fairness of high income concentration, most people respond that it crucially depends on how those in the top got there. If success depends on "hard work" or "willingness to take risk”, people seem to tolerate inequality - even high degrees of it. If, on the other hand, the

\footnotetext{
${ }^{1}$ Starting with Piketty (2001), Atkinson (2004), and Piketty and Saez (2003), a number of studies have followed using a common methodology to create homogenous series of top income shares over the long run for a number of mainly industrialized countries. Roine and Waldenström (2008) and Gustafsson and Jansson (2008) study the Swedish case. Atkinson and Piketty (2007) survey much of this work, its methodology and main findings.

${ }^{2}$ For example, the top income literature has shown that the top decile is typically a very heterogeneous group both in terms of income composition (though the composition has also changes over time for some groups) and in terms of the volatility of their income share. For most countries it also seems that most of the movement in the share of the top decile group is, in fact, driven by the top percent (something which runs the risk of not being captured if data is based on smaller, often top-coded samples.
} 
rich have reached their position because of inheritance, a certain family environment, or “connections and knowing the right people”, this is generally viewed as unfair. ${ }^{3}$ Atkinson and Piketty (2007) point out that the change in top income composition in Anglo-Saxon countries, where top wage earners have replaced capital income earners, indicate that today's income top is not primarily based on inherited wealth. This is supported by the findings in Kopczuk and Saez (2004), who show that the recent increase in income concentration in the U.S has not been accompanied by any major increase in wealth concentration, and by Edlund and Kopczuk (2008), who proxy wealth mobility in the U.S. by the share of women in the top of the distribution, and find that this share has decreased substantially over the past decades, also indicating a decreasing role for inheritance among the rich. ${ }^{4}$ While these studies are indicative of changes in mobility, no previous study has been able to explicitly study intergenerational mobility of top incomes. ${ }^{5}$

The second motivation for our study is an interest in the workings of the extensive welfare state. Broadly defined as having an exceptional commitment to economic security and egalitarianism, the "Nordic model” has received much attention and its achievements in equalizing income and mitigating poverty are well known. ${ }^{6}$ What seems less well known is the fact that the financing of these welfare states has primarily rested on high average taxes rather than highly progressive taxes. Furthermore, this has been combined with relatively low capital taxes (at times even negative due to generous deductions) indicating a desire to combine high

\footnotetext{
${ }^{3}$ The quotes are formulations from a Gallup pole used in Fong (2001), but there are many other examples of similar formulations in, for example, the World Values Survey, the General Social Survey, the International Social Survey, the International Social Justice Project, etc. Some studies have focused on the differences in perceptions of why people are rich or poor, and, in particular on the differences between the US and Europe with respect to such beliefs (e.g., Alesina, Glaeser and Sacerdote, 2001, and Alesina and Glaeser, 2004). However, the opinion that if a person is rich as a consequence of working hard this is fair (and vice versa if the person has not made any effort) seems to be shared across countries. For example, Jencks and Tach (2006) report that a majority of people in Germany, Japan, U.K. and the U.S. agreed with the statement that "[inequality] is fair but only if there are equal opportunities" (based on data collected by the International Social Justice Project (ISJP) in 1991). ${ }^{4}$ Kopczuk, Saez and Song (2007) study within lifetime income mobility in the U.S. and find that the probability of remaining in the top percent of the distribution from one period to the next has changed very little over the past decades.

${ }^{5}$ It may at first seem odd that we know so little about intergenerational income mobility at the top. However, when one considers the progress made in intergenerational income mobility research over the past 15 years it becomes less of a puzzle. A central insight in the work following Solon (1992) and Zimmerman (1992) is that taking data requirements seriously is crucial for correctly estimating intergenerational mobility and when it comes to estimating life-time incomes for two generations focusing on fractions as small as 0.1 percent this requires very large datasets. The only study we know of which has previously studied intergenerational mobility for fractions as small as the top percent of the distribution is by Corak and Heisz (1999) on Canadian data.

${ }^{6}$ See Gottschalk and Smeeding (1997) for Nordic income distribution in international perspective, Lindbeck (1997) for an examination of the Swedish welfare state, and Björklund and Freeman (2008) for a recent overview of income equalization in Sweden.
} 
egalitarian ambitions with good investment incentives for large capital holders. ${ }^{7}$ The extent to which this has been a strategy or a result of pragmatism in the face of increasing mobility of capital is debatable. It nevertheless gives rise to a number of interesting questions regarding mobility of Swedish top income earners. Is it the case that there are large differences in mobility when contrasting earnings and total income? If so, are these differences particularly important in the top of the distribution? Is there evidence that equality of opportunity in Sweden has been conditional on not aspiring for the very top of the distribution? ${ }^{8}$

Our study's answer to all of these questions is “yes”. Using the same income concepts as in previous work on top incomes we find that: 1 ) intergenerational earnings mobility is generally higher than total income mobility, 2) mobility is generally smaller the higher up in the distribution and, perhaps most importantly, 3) for total income it becomes exceptionally low at the very top of the distribution. In this sense Sweden does indeed seem to fit the picture of a society where equality of opportunity for wage earners coexists with capitalistic dynasties. In line with previous studies of top incomes, our results also emphasize the need to study small fractions of the population in order to fully understand income mobility.

The rest of the paper continues with a presentation of econometric models in section 2, followed by data description in section 3. Main results are reported in section 4, followed by sensitivity analyses in section 5 . Section 6 concludes and discusses topics for future research.

\section{Econometric models}

Our point of departure is the prototypical model in intergenerational income mobility research

$$
y_{s i}=\alpha+\beta y_{f i}+\varepsilon_{i}
$$

where $y_{s i}$ is the income of a son in family $i$ and $y_{f i}$ the corresponding measure for his father. We strive for estimating the intergenerational relationship between long-run incomes following the standard approach in the literature, and therefore use multi-year average incomes

\footnotetext{
${ }^{7}$ For example, Steinmo (1993) and Lindert (2004) contain discussions of this as well as numerous references.

${ }^{8}$ Previous work on intergenerational mobility in Sweden suggests that mobility is in general comparatively high in Sweden (see Björklund and Jäntti, 2009, for a cross-national comparison). To the extent that previous work examines differences across the income distribution, the top group is defined as a rather broad group, such as the top-quintile group in Jäntti et al. (2006).
} 
throughout. We also control for father's and son's age (linearly and quadratically) in all our regressions.

The regression coefficient $\beta$ is the intergenerational elasticity, i.e., it measures the percentage differential in sons' expected income with respect to a marginal percentage differential in the incomes of fathers. In case the variance of long-run incomes in both generations is the same, the elasticity is also the intergenerational correlation in log incomes. In our study, the distinction between the elasticity and the correlation is not relevant since we focus on the intergenerational transmission in the very top of the distributions.

We extend equation (1) in two ways to address two different questions. ${ }^{9}$ First, we use nonlinear regression by means of a spline function with knots (chosen by us), which are income levels in the distribution of fathers' incomes at which the slope is allowed to change (see Greene, 1997, pp. 388f). In this way, when estimated on knots in the top of the distribution, our parameters show the percentage differential in sons' expected income with respect to marginal differentials in the top of the fathers' distribution. The specified model now looks as follows for knot $k$, which in our case simply is a level of income corresponding to a certain percentile $p$ in the fathers' distribution (in our estimations we include eight knots):

$$
y_{s i}=\alpha+\beta y_{f i}+\delta_{p}\left(y_{f i}-k_{p}\right)+\varepsilon_{i}
$$

Our second approach is to use quantile regressions to analyze how sensitive the $q$ th percentile in the sons' income distribution is to the fathers' incomes (see Koenker and Hallock, 2001). When $q$ is a top income quantile, say the 99th percentile, our estimated parameter tells us how sensitive the top in sons' income distribution is to differentials in fathers incomes. Thus we specify the following equation for each quantile $q$ :

$$
y_{s i}=\alpha^{q}+\beta^{q} y_{f i}+\varepsilon_{i}^{q}
$$

\footnotetext{
${ }^{9}$ Grawe (2004) uses a model that combines our two approaches, namely spline and quantile regression. However, this combination is not feasible for us as our focus on the very top of the distribution gives small samples.
} 


\section{Data}

We use Swedish data compiled from administrative registers run by Statistics Sweden. First, we use the multi-generational register to connect biological fathers and their sons. We then use income registers to add income and earnings data, based on compulsory reports from employers to tax authorities or from personal tax returns.

The starting point for constructing our population is a random sample of 35 percent of all men born in Sweden between 1960 and 1967. These are the sons in our study and we observe their incomes during 1996-2005, i.e., when they are in their 30s and early 40s. This is a period in life when even annual incomes are shown to be unbiased proxies for lifetime income with only classical measurement errors (Böhlmark and Lindquist, 2006). Yet, we average their annual incomes over the entire ten-year period in order to eliminate a large part of the transitory fluctuations.

When measuring fathers' incomes, we also want a good proxy for long-run income. There are, however, also arguments for measuring income at the time when their children grew up since this captures important determinants of the intergenerational transmission of incomes. In fact, several previous studies in the intergenerational literature have chosen to measure fathers' incomes in this way. ${ }^{10}$ When measuring fathers' incomes in Sweden, the choice of years is restricted by the fact that consistent income data are available only from 1974 onwards. ${ }^{11}$ For this reason, we measure parental income as the average of income during the years 19741979, i.e., when their sons were between seven and nineteen years old and thus mostly living with their parents.

We use two concepts of income. The first is total income, which is income from all sources (labor, business, capital and realized capital gains) before taxes and transfers. ${ }^{12}$ This is the same measure as the top income studies have used when studying the evolution of top income shares. ${ }^{13}$ Our estimates of the intergenerational mobility in the top, hence, correspond directly

\footnotetext{
${ }^{10}$ See Corak (2006) and Björklund and Jäntti (2009) for recent surveys.

${ }^{11}$ Although we observe incomes since 1968, there was a legal change in 1973-74 that made a set of social insurance benefits taxable and from then on also included in the income data. As a consequence, to get fully comparable measures of income and earnings we choose 1974 as our starting date.

${ }^{12}$ Total income (sammanräknad nettoinkomst for fathers and summa förvärvs- och kapitalinkomst for sons) also includes taxable social insurance benefits such as unemployment insurance, pensions, sickness pay and parental leave benefits.

${ }^{13}$ See Roine and Waldenström (2008).
} 
to their estimates of the static inequality in the income top. Our second measure is earnings, which includes income from work for employees and self-employed. ${ }^{14}$

Several specific problems arise when measuring incomes and earnings in the absolute top of the distribution. We feel broadly confident with the Swedish register data used in this study for example there is no such thing as top coding in the income and earnings registers. Yet there are two important sources of measurement error that potentially influence our results. ${ }^{15}$

First, our earnings measure never includes capital incomes even though items such as bonuses and realized stock options can be a relatively important form of compensation to top earners. To the extent that such capital-based reimbursements have become more prevalent since the 1970s, which is arguably the case in Sweden, we systematically underestimate top earnings among sons. Since this mismeasurement of the dependent variable ought to be positively correlated with father's earnings, we are at risk of biasing the estimated relationship downwards and overestimating earnings mobility across generations.

Second, after Sweden around 1990 liberalized its capital account there has been a drastic increase in cross-border capital movements among the wealthy. In a recent survey of the Swedish household wealth concentration, Roine and Waldenström (2009) show that significant shares of wealth owned by the richest Swedes may be placed in off-shore locations. As a result, capital income among high-income earning sons could be underestimated. Since measurement error is likely to be positively correlated with fathers' earnings, we risk overestimating intergenerational income mobility. Altogether, we may not fully capture all incomes and earnings accruing to the top, which could bias our results. Fortunately, the biases all go in the same direction, namely that we tend to overestimate intergenerational mobility and especially so in the very top of the distribution.

\footnotetext{
${ }^{14}$ Earnings (arbetsinkomst) is an income concept created by Statistics Sweden by combing wages and salaries and business income. It also includes earnings-related short-term sickness benefits and parental-leave benefits but not unemployment and (early) retirement benefits.

${ }^{15}$ Statistics Sweden's income and earnings data rely on personal tax assessments through 1977 for wages, salaries, and transfers, and through 1987 for interests and dividends. Thereafter reports come from employers (and authorities for transfers) and banks respectively. Thus, our sons' data come from employers and banks and most of our fathers' data come from personal reports. Most likely, the latter source introduces some measurement error in fathers' income resulting in an underestimation of intergenerational transmission, and consequently, an overestimation of mobility.
} 
When determining the population used in the estimations, we begin by requiring fathers to be residents all the years 1974-1979 and sons in all the years 1996-2005. We then use separate samples for income and earnings and use only the son-father pairs for whom both had positive income observations each observation year, and do correspondingly in the earnings sample. ${ }^{16}$ For reasons that we will return to, we are somewhat concerned about the presence of observations with zero income and earnings, and therefore perform some sensitivity analyses to examine whether our basic conclusions are sensitive to the treatment of these observations.

Table 1 reports descriptive statistics for fathers in the two samples of our main analysis. Our income sample contains 130,047 pairs of fathers and sons and the earnings sample contains 101,635 pairs. ${ }^{17}$ Thus we observe more than thousand father-son pairs in the top income percentile and over one hundred in the top 0.1 percentile group. ${ }^{18}$ The mean and median are about the same for income and earnings. Top incomes are substantially higher than top earnings, with the highest income observation being 2-3 times larger than the highest earnings observation. This difference clearly underscores the importance of large capital incomes for top incomes. The age of fathers is somewhat higher in the income sample, which is plausible given than few fathers have positive earnings after their retirement at the age of $65 .{ }^{19}$

\section{[Table 1]}

In Table 2, we report similar characteristics for sons. The levels of inequality are quite different across both generations and income concepts. In the case of total incomes, the coefficient of variation increased from around 0.5 for fathers to over 1.0 for sons and the standard deviation of the average of log incomes increased from 0.43 to 0.49 . By contrast, the coefficient of variation for earnings increased only modestly from 0.48 for fathers to 0.57 for sons and the standard deviation of average of log earnings even fell from 0.56 to 0.49 . These numbers are

\footnotetext{
${ }^{16}$ Our income and earnings data come in units of 1 SEK for all but two years when they come in 100 SEK. We adjust for this in our analysis by multiplying incomes and earnings in the two latter years by 100 . Still, there may be a concern that when taking logs of incomes near the lowest income limit the initial difference in limits could influence the results. Rerunning the main analysis requiring incomes and earnings to be at least 100 SEK instead of just being positive, however, the results (available upon request) do not change.

${ }^{17}$ These numbers can be compared to 151,148 sons who were born in Sweden in 1960-67 and resided in Sweden all years 1996-2005, that is, the population we want to make inferences about. Table A1 explains how the sample changes depending on the requirements we have.

${ }^{18}$ As a striking comparison, note that Solon (1992) in his seminal study for the United States had some 250 pairs of fathers and sons who lived together in the same PSID household in 1968.

${ }^{19}$ We checked whether the fact that fathers in the income sample are relatively older influence the results, but found that they did not by running the analysis using only fathers aged 65 or less in both populations (results are available upon request).
} 
in line with the previously documented trends for top income shares in Sweden, which indicate sharp increases for total income but only moderate changes for earnings (see Roine and Waldenström, 2008, for details).

[Table 2]

\section{Results}

Our main results are reported in Table 3. The conventional least squares regression model (1) yields estimates of the intergenerational elasticity of 0.262 for income and 0.169 for earnings. While this difference between income and earnings might appear as striking, it should be noticed that they also differ in terms of trends in dispersion. Specifically, using information from data in the above section 3, the ratio of the standard deviation of fathers' and sons' long-run incomes fell by 12 percent $(0.43 / 0.49)$ and the corresponding ratio increased by 14 percent (0.56/0.49) for earnings. In other words, the intergenerational correlations (defined as the estimated intergenerational elasticities multiplied by the ratio of the standard deviations) are 0.23 and 0.19 in the two cases. These numbers are by and large in line with previous results for Sweden.

[Table 3]

Next, we turn to the pattern in the top of the distribution. The results using the spline specification (2) indicate a clear non-linear pattern in the persistence of sons' incomes in different levels of fathers' incomes or earnings. Specifically, in the lowest quartile, the generational dependency is almost absent, with regression coefficients of 0.106 for incomes and 0.042 for earnings. For fathers between the 25th and 99th percentiles, generational persistence is higher. Coefficient estimates vary between 0.16 and 0.42 , with the highest coefficient for incomes in the "upper middle class", i.e., between the median and 90th percentile. The most striking finding, however, is that the persistence increases drastically in the absolute income top. For fathers with incomes in the top 0.1 percentile, we estimate a coefficient of 0.827 with a standard error as low as 0.099. Taken at face value, this coefficient implies that a 10 percent income differential among high-income fathers is transmitted into an 8.3 percent differential among sons. This should be contrasted against the average transmission found in model (1), which is only 2.6 percent. 
In the quantile regressions (3), we examine how sensitive sons' incomes and earnings at different levels are to their fathers' incomes and earnings. Here, the results reveal basically the same non-linear patterns as we saw in the spline regression analysis. In the case of incomes, there is a somewhat smoother increase in the degree of persistence across generation over the level of sons' incomes. The median regression, $q 50$, has an intergenerational elasticity of 0.233. This is lower than in the OLS regression, but that is expected given the skewness of the income distribution. Already by the 75th quantile, we observe coefficients of 0.296 and for q99-coefficient it is 0.381 , which implies that a 10 percent income differential among fathers is related to a 3.8 percent higher income for sons' at the 99th quantile of the distribution. Going even further up the income distribution, we find a coefficient of 0.531 at $q 99.9$, which is markedly higher than elsewhere in the distribution.

Turning to earnings, we find qualitatively similar patterns but a much weaker increase in persistence toward the top. The coefficients at the top are only half as large as they are for income. This difference among income and earnings suggests that it is the capital income component that is strongly inherited at the very top of the distribution.

Altogether, while our results corroborate previous findings on average Swedish income mobility they also highlight new evidence on notable non-linearities in this relationship across the distribution of income. Specifically, we find mobility to be high among low-income earners but that it diminishes notably in the middle-income classes. In the absolute top of the distribution we find remarkably low levels of income mobility. Among fathers in the top 0.1 percentile there is almost no intergenerational mobility at all.

These non-linear mobility patterns also prevail in the earnings distribution, but to a much lesser extent. There even seems to be a considerable equality of opportunity for wage earners in the Swedish economy, with low-wage earning fathers transmitting almost none of their earnings status to their sons. In the absolute top, earnings mobility is only slightly higher than mobility at the income median. Possibly this relatively high level of mobility in the earnings top could in part be due to the omission of capital incomes accruing to high-wage earning sons, which, as discussed above, leads to an overestimation of earnings mobility. 


\section{Sensitivity analyses}

We now turn to sensitivity analyses. First, we ask whether the interesting difference in results for income and earnings is driven by the fact that the estimations in Table 3 were done on two different samples. In panel Table 4a, we report estimates for the same models as in Table 3, but on requiring that fathers had both positive incomes and positive earnings each year 19741979 (giving us the same sample when estimating earnings and incomes, respectively). The results are similar to those in our main specification. If anything, coefficients in the very top of are higher, suggesting that top mobility could be even lower than indicated by our main results.

[Table 4a]

The motivation for the other sensitivity analyses is that we are concerned about the interpretation of observations with zero annual income (or earnings). On one hand, both income and earnings might correctly be zero. In particular, our register information might correctly report zero earnings income for a person who has studied the whole year, been unemployed the whole year or left the labor force (for retirement or something else) for the whole year. In some of these cases, in particular unemployment, retirement and long-term sickness, we could expect the person to collect some taxable social transfers but not necessarily for those who study. On the other hand, there is also a possibility that income or earnings in our data is recorded zero by mistake. One example is if the tax declaration process is not completed and subject to a judicial process.

Our strategy is to make two extreme assumptions about the possible nature of the zero income observations and investigate whether our main results would change substantially. Looking first at the case where we treat the zero income/earnings observations as being incorrect and use average of log income for the remaining years, the main results are not changed, see table 4b.

[Table 4b]

Finally, treating the zero income/earnings observations as being correct we calculate the log of average income for all years treating zeros as just zeros. As can be seen in Table 4c, this 
does not seem to change the main results either. This approach, however, also involves the change of functional form since we now use the log of average income for all years instead of the average of the log of annual income observations. In order to investigate whether this change is important, we go back to the assumption in Table $4 \mathrm{~b}$ and treat zero observations as incorrect but use the log of the average of income instead of the average of the log. The results in Table 4d show that our main results are robust with respect to this assumption as well.

[Table 4c]

[Table 4d]

\section{Conclusions and suggestions for future research}

Analogously to the top income literature, a first general conclusion that can be drawn from our results is that it is crucial to study small fractions in the top of the distribution to get a clear picture of income mobility. Discussing “the top” as consisting of the top 20, or top 10, or even the top 5 percent, runs the risk of missing important aspects. Indeed, our most striking results do not show until within the top percentile. Furthermore, as is also suggested by the top income literature, it is important to separate different sources of income, in particular to separate between earnings and income including capital income.

While our results are clear in showing higher persistence in total income mobility compared to earnings mobility, as well as in showing sharp increases in persistence for the very top groups, some questions still remain in terms of interpretation. First, and most importantly, we can not distinguish the "qualitative source" of capital incomes. The concepts of capital income and realized capital gains may both contain income from stock options or the sale of a company built by the individual who reports the income, as well as income flowing from inherited capital. The former are connected to an individuals work efforts while the latter are based on inheritance of wealth. Typically we would like to distinguish these when making interpretations. Importantly though, the fact that top capital incomes may be related to work effort, does not alter the fact that those who receive such compensation also had fathers with similar positions in the income distribution. Second, the fact that we focus on persons residing in Sweden over the period means that our estimates do not include those who have chosen to move abroad. To the extent that such moves have, for example, been more common among 
individuals who have made their own fortunes, these "mobile" top income earners are not captured in our sample. Again, this does not take away the result that among those who reside in Sweden persistence in the top is very high.

Our results suggest several interesting avenues for further research. To begin with, we have followed much of the previous research and confined the analysis to men. Obviously, it would be interesting to incorporate mothers and daughters too. It would also be fascinating to consider the role of parents-in-law and thus assortative mating in a study of intergenerational inheritance of top incomes and earnings. Chadwick and Solon (2002) have shown that this can be done in a straightforward way by using family income of parents and offspring.

Finally, our results can at present be given two different comparative interpretations. Either the combination of high overall earnings mobility and extremely high income persistence in the top is a unique feature of the extensive welfare state, perhaps even a consequence of the particular "Nordic model”, or, alternatively, income persistence in the top is just as high, or even higher, in societies like the U.S. where overall mobility is lower than in Sweden. Determining which is right requires studies of top income mobility for other countries.

\section{References}

Alesina, Alberto, Edward Glaeser, and Bruce Sacerdote. 2001. "Why Doesn't the United States Have a European-Style Welfare State?” Brookings Papers on Economic Activity, 2: $1-69$.

Alesina, Alberto and Edward Glaeser. 2004. Fighting Poverty in the U.S. and Europe: A World of Difference. Oxford University Press.

Atkinson, Anthony B. 2004. "Top Incomes in the UK over the Twentieth Century.” Journal of the Royal Statistical Society, Series A, 168(2): 325-343.

Atkinson, Anthony B. and Thomas Piketty (eds.). 2007. Top Incomes over the Twentieth Century - A Contrast between European and English-Speaking Countries, Oxford University Press.

Björklund, Anders and Richard B. Freeman. 2008. "Searching for Optimal Inequality/Incentives.” NBER Working Paper no. 14014.

Björklund, Anders and Markus Jäntti. 2009. "Intergenerational Income Mobility and the Role of Family Background”, forthcoming in Oxford Handbook of Economic Inequality, Oxford University Press, Oxford.

Bowles, Samuel and Herbert Gintis. 2002. “The Inheritance of Inequality.” Journal of Economic Perspectives, 16(3): 3-30. 
Böhlmark, Anders and Matthew Lindquist. 2006. "Life-Cycle Variations in the Association between Current and Lifetime Income: Replication and Extension for Sweden.” Journal of Labor Economics, 24(4): 879-900.

Chadwick Laura and Gary Solon. 2002. "Intergenerational Income Mobility Among Daughters.” American Economic Review, 92(1): 335-44.

Corak, Miles. 2006. "Do Poor Children Become Poor Adults? Lessons from a Cross-Country Comparison of Generational Earnings Mobility.” Research on Economic Inequality, 13(1): 143-188.

Corak, Miles and Andrew Heisz. 1999. "The Intergenerational Earnings and Income Mobility of Canadian Men: Evidence from Longitudinal Income Tax Data.” Journal of Human Resources, 34(3): 504-533.

Edlund, Lena and Wojciech Kopczuk. 2008. "Women, Wealth, and Mobility.” forthcoming in the American Economic Review.

Fong, Christina. 2001. "Social Preferences, Self-Interest, and the Demand for Redistribution.” Journal of Public Economics, 82(2): 225-46.

Gottschalk, Peter and Timothy M. Smeeding. 1997. "Empirical Evidence on Income Inequality in Industrialized Countries” in A.B. Atkinson and F. Bourgignon (eds.), The Handbook of Income Distribution. London: North Holland Press.

Grawe, Nathan. 2004. "Reconsidering the Use of Nonlinearities in Intergenerational Earnings Mobility as a Test for Credit Constraints”. Journal of Human Resources 39/3: 813-27.

Greene, William H. 1997. Econometric Analysis, 3rd Edition, Prentice Hall, Upper Saddle River, NJ.

Gustafsson, Björn and Birgitta Jansson. 2008. “Top incomes in Sweden over three-quarters of a century: a micro data approach”, forthcoming in Cambridge Journal of Economics.

Jencks, Christopher and Laura Tach. 2006. "Would Equal Opportunity Mean More Mobility?”, in S.L. Morgan, D.B. Grusky, G.S. Fields (eds.), Mobility and Inequality, Stanford University Press.

Jäntti, Markus, Bernt Bratsberg, Knut Roed, Odbdjoern Raaum, Robin Naylor, Eva Österbacka, Anders Björklund and Tor Eriksson. 2006. "American Exceptionalism in a New Light: A Comparison of Intergenerational Earnings Mobility in the Nordic Countries.” IZA DP no. 1938.

Koenker, Roger and Kevin F. Hallock. 2001. “Quantile Regression.” Journal of Economic Perspectives, 15(4): 143-156.

Kopzcuk, Wojciech, Emmanuel Saez and Jae Song. 2007. "Uncovering the American Dream: Inequality and Mobility in Social Security Earnings Data since 1937.” NBER Working Paper No. 13345.

Lindbeck, Assar. 1997. “The Swedish Experiment.” Journal of Economic Literature, 25(3): 1273-1319.

Lindert, Peter H. 2004. Growing Public: Social Spending and Economic Growth since the Eighteenth Century (Two volumes). Cambridge: Cambridge University Press.

Piketty, Thomas. 2001. Les hauts revenus en France au 20ème siècle. Grasset, Paris.

Piketty, Thomas. 2003. “Income Inequality in France, 1900-1998.” Journal of Political Economy, 111(5): 1004-1042. 
Piketty, Thomas and Emmanuel Saez. 2003. "Income Inequality in the United States, 19131998.” Quarterly Journal of Economics, 118(1): 1-39.

Roine, Jesper and Daniel Waldenström. 2008. "The Evolution of Top Incomes in an Egalitarian Society: Sweden, 1903-2004.” Journal of Public Economics, 9(1-2): 366-387.

Roine, Jesper and Daniel Waldenström. 2009. "Wealth Concentration over the Path of Development: Sweden, 1873-2006.” Scandinavian Journal of Economics, forthcoming.

Saez, Emmanuel, and Michael Veall. 2005. "The Evolution of High Incomes in Northern America: Lessons from Canadian Evidence.” American Economic Review, 95(3): 831-849.

Solon, Gary. 1992. “Intergenerational Income Mobility in the United States.”, American Economic Review, 82(3): 393-408.

Solon, Gary. 1999. "Intergenerational Mobility in the Labor Market,” in O. Ashenfelter and D. Card (eds.) Handbook of Labor Economics vol. 3A. Elsevier, Amsterdam, North Holland.

Steinmo, Sven. 1993. Taxation and democracy: Swedish, British and American approaches to financing the modern state. Yale University Press, New Haven.

Zimmermann, David J. 1992. "Regression Toward Mediocrity in Economic Stature.” American Economic Review, 82(3): 409-29. 
TABLES

Table 1: Descriptive statistics for main income and earnings samples, fathers.

\begin{tabular}{|c|c|c|c|c|c|c|c|c|c|c|c|}
\hline Variable & Concept & Mean & S.D. & Min & $\mathrm{P} 25$ & $\mathrm{P} 50$ & P75 & P90 & P95 & P99 & Max \\
\hline \multirow{2}{*}{ Age in 1974} & Income & 40.6 & 7.3 & 22 & 35 & 40 & 45 & 51 & 54 & 60 & 81 \\
\hline & Earnings & 40.2 & 6.9 & 22 & 35 & 39 & 45 & 50 & 53 & 58 & 76 \\
\hline \multirow{2}{*}{1974} & Income & 247 & 144 & .1 & 181 & 217 & 276 & 373 & 464 & 785 & 9,882 \\
\hline & Earnings & 244 & 129 & .0 & 183 & 219 & 277 & 373 & 460 & 761 & 3,747 \\
\hline \multirow{2}{*}{1979} & Income & 252 & 140 & .3 & 187 & 226 & 287 & 382 & 471 & 757 & 12,263 \\
\hline & Earnings & 258 & 130 & .3 & 194 & 231 & 292 & 386 & 474 & 747 & 4,573 \\
\hline \multirow{2}{*}{ Ave(74-79) } & Income & 254 & 137 & 3.1 & 189 & 225 & 283 & 380 & 468 & 764 & 13,950 \\
\hline & Earnings & 256 & 124 & 1.4 & 194 & 228 & 287 & 383 & 468 & 748 & 4,467 \\
\hline \multirow{2}{*}{ Ave $(\ln 74-\ln 79)$} & Income & 12.34 & 0.43 & 7.74 & 12.14 & 12.32 & 12.55 & 12.84 & 13.05 & 13.53 & 16.39 \\
\hline & Earnings & 12.32 & 0.56 & 5.70 & 12.16 & 12.33 & 12.56 & 12.85 & 13.05 & 13.51 & 15.24 \\
\hline
\end{tabular}

Note: The income (earnings) sample consists of father-son pairs with positive income (earnings) all years. Incomes and earnings are in thousand 2005 SEK. Observations are 130,047 (incomes) and 101,635 (earnings).

Table 2: Descriptive statistics for main income and earnings samples, sons.

\begin{tabular}{llrrrrrrrrrrr}
\hline Variable & Concept & Mean & S.D. & Min & P25 & P50 & P75 & P90 & P95 & P99 & Max \\
\hline \multirow{2}{*}{ Age in 1996 } & Income & 32.3 & 2.3 & 29 & 30 & 32 & 34 & 36 & 36 & 36 & 36 \\
& Earnings & 32.3 & 2.3 & 29 & 30 & 32 & 34 & 36 & 36 & 36 & 36 \\
\hline \multirow{2}{*}{1996} & Income & 236 & 201 & .0 & 179 & 223 & 273 & 346 & 411 & 594 & 37,113 \\
& Earnings & 236 & 118 & .0 & 187 & 231 & 281 & 352 & 412 & 569 & 7,158 \\
\multirow{2}{*}{2000} & Income & 329 & 1,328 & .0 & 216 & 267 & 342 & 476 & 594 & 1,125 & 347,553 \\
& Earnings & 310 & 232 & .0 & 228 & 276 & 352 & 474 & 572 & 901 & 27,566 \\
\multirow{2}{*}{2005} & Income & 354 & 423 & .0 & 237 & 297 & 388 & 544 & 691 & 1,311 & 45,223 \\
& Earnings & 350 & 229 & .0 & 250 & 308 & 400 & 546 & 676 & 1,099 & 10,802 \\
\multirow{2}{*}{ Ave(96-05) } & Income & 303 & 316 & .2 & 217 & 263 & 333 & 452 & 557 & 936 & 43,346 \\
& Earnings & 302 & 171 & 1.6 & 224 & 271 & 342 & 455 & 544 & 820 & 13,051 \\
\hline \multirow{2}{*}{ Ave(ln96-ln06) } & Income & 12.45 & 0.49 & 3.13 & 12.25 & 12.46 & 12.69 & 12.98 & 13.18 & 13.60 & 17.50 \\
& Earnings & 12.46 & 0.49 & 5.94 & 12.28 & 12.49 & 12.72 & 13.00 & 13.17 & 13.56 & 16.10 \\
\hline \hline
\end{tabular}

Note: See table 1. 
Table 3: Main results for basic samples. $\mathrm{N}=130,047$ (incomes); $\mathrm{N}=101,635$ (earnings)..

\begin{tabular}{|c|c|c|c|c|c|c|c|c|}
\hline Income: & OLS & $q 25$ & $q 50$ & $q 75$ & $q 90$ & $q 95$ & $q 99$ & $q 99.9$ \\
\hline OLS & $\begin{array}{c}0.262 \\
(0.003)\end{array}$ & & & & & & & \\
\hline Quantile & & $\begin{array}{c}0.189 \\
(0.004)\end{array}$ & $\begin{array}{c}0.233 \\
(0.003)\end{array}$ & $\begin{array}{c}0.296 \\
(0.004)\end{array}$ & $\begin{array}{c}0.331 \\
(0.005)\end{array}$ & $\begin{array}{c}0.338 \\
(0.006)\end{array}$ & $\begin{array}{c}0.381 \\
(0.011)\end{array}$ & $\begin{array}{c}0.531 \\
(0.033)\end{array}$ \\
\hline & $p<25$ & $25<p<50$ & $50<p<75$ & $75<p<90$ & $90<p<95$ & $95<p<99$ & $99<p<99.9$ & $99.9<p$ \\
\hline Spline & $\begin{array}{c}0.106 \\
(0.007)\end{array}$ & $\begin{array}{c}0.352 \\
(0.027)\end{array}$ & $\begin{array}{c}0.347 \\
(0.026)\end{array}$ & $\begin{array}{c}0.422 \\
(0.027)\end{array}$ & $\begin{array}{c}0.260 \\
(0.051)\end{array}$ & $\begin{array}{c}0.222 \\
(0.034)\end{array}$ & $\begin{array}{c}0.344 \\
(0.073)\end{array}$ & $\begin{array}{c}0.827 \\
(0.099)\end{array}$ \\
\hline Earnings & OLS & $q 25$ & $q 50$ & $q 75$ & $q 90$ & $q 95$ & $q 99$ & $q 99.9$ \\
\hline$\overline{\text { OLS }}$ & $\begin{array}{c}0.169 \\
(0.003)\end{array}$ & & & & & & & \\
\hline Quantile & & $\begin{array}{c}0.154 \\
(0.005) \\
\end{array}$ & $\begin{array}{c}0.158 \\
(0.003) \\
\end{array}$ & $\begin{array}{c}0.170 \\
(0.004)\end{array}$ & $\begin{array}{c}0.169 \\
(0.003)\end{array}$ & $\begin{array}{c}0.160 \\
(0.005) \\
\end{array}$ & $\begin{array}{c}0.164 \\
(0.006) \\
\end{array}$ & $\begin{array}{c}0.252 \\
(0.012) \\
\end{array}$ \\
\hline & $p<25$ & $25<p<50$ & $50<p<75$ & $75<p<90$ & $90<p<95$ & $95<p<99$ & $99<p<99.9$ & $99.9<p$ \\
\hline Spline & $\begin{array}{c}0.042 \\
(0.004)\end{array}$ & $\begin{array}{c}0.417 \\
(0.031)\end{array}$ & $\begin{array}{c}0.398 \\
(0.029)\end{array}$ & $\begin{array}{c}0.409 \\
(0.032)\end{array}$ & $\begin{array}{c}0.291 \\
(0.061)\end{array}$ & $\begin{array}{c}0.157 \\
(0.041)\end{array}$ & $\begin{array}{c}0.319 \\
(0.091)\end{array}$ & $\begin{array}{c}0.355 \\
(0.160)\end{array}$ \\
\hline
\end{tabular}

Note: All models reported in this and the following tables are estimated with linear and quadratic controls for father's and son's age. Corresponding to our models $q$ and $p$ are short for quantile and percentile respectively. Standard errors are in parenthesis and in the quantile regressions, these are bootstrapped using 30 replications.

Table 4a) Same sample for income and earnings. Positive income and earnings each year for both sons and fathers. $\mathrm{N}=101,519$.

\begin{tabular}{|c|c|c|c|c|c|c|c|c|}
\hline Income: & OLS & $q 25$ & $q 50$ & $q 75$ & $q 90$ & $q 95$ & $q 99$ & $q 99.9$ \\
\hline$\overline{\text { OLS }}$ & $\begin{array}{c}0.294 \\
(0.003)\end{array}$ & & & & & & & \\
\hline Quantile & & $\begin{array}{c}0.186 \\
(0.005)\end{array}$ & $\begin{array}{c}0.273 \\
(0.004)\end{array}$ & $\begin{array}{c}0.352 \\
(0.004)\end{array}$ & $\begin{array}{c}0.379 \\
(0.005)\end{array}$ & $\begin{array}{c}0.388 \\
(0.007)\end{array}$ & $\begin{array}{c}0.466 \\
(0.015)\end{array}$ & $\begin{array}{c}0.630 \\
(0.033)\end{array}$ \\
\hline & $p<25$ & $25<p<50$ & $50<p<75$ & $75<p<90$ & $90<p<95$ & $95<p<99$ & $99<p<99.9$ & $99.9<p$ \\
\hline Spline & $\begin{array}{c}0.097 \\
(0.009)\end{array}$ & $\begin{array}{c}0.351 \\
(0.028)\end{array}$ & $\begin{array}{c}0.377 \\
(0.024)\end{array}$ & $\begin{array}{c}0.440 \\
(0.026)\end{array}$ & $\begin{array}{c}0.286 \\
(0.049)\end{array}$ & $\begin{array}{c}0.243 \\
(0.032)\end{array}$ & $\begin{array}{c}0.400 \\
(0.068)\end{array}$ & $\begin{array}{c}0.741 \\
(0.092)\end{array}$ \\
\hline Earnings & OLS & $q 25$ & $q 50$ & $q 75$ & $q 90$ & $q 95$ & $q 99$ & $q 99.9$ \\
\hline$\overline{\text { OLS }}$ & $\begin{array}{c}0.168 \\
(0.003)\end{array}$ & & & & & & & \\
\hline Quantile & & $\begin{array}{c}0.154 \\
(0.005)\end{array}$ & $\begin{array}{c}0.158 \\
(0.004)\end{array}$ & $\begin{array}{c}0.170 \\
(0.004)\end{array}$ & $\begin{array}{c}0.169 \\
(0.003)\end{array}$ & $\begin{array}{c}0.160 \\
(0.004)\end{array}$ & $\begin{array}{c}0.164 \\
(0.006)\end{array}$ & $\begin{array}{c}0.252 \\
(0.021)\end{array}$ \\
\hline & $p<25$ & $25<p<50$ & $50<p<75$ & $75<p<90$ & $90<p<95$ & $95<p<99$ & $99<p<99.9$ & $99.9<p$ \\
\hline Spline & $\begin{array}{c}0.042 \\
(0.004) \\
\end{array}$ & $\begin{array}{c}0.417 \\
(0.031)\end{array}$ & $\begin{array}{c}0.397 \\
(0.029) \\
\end{array}$ & $\begin{array}{c}0.409 \\
(0.032) \\
\end{array}$ & $\begin{array}{c}0.287 \\
(0.061) \\
\end{array}$ & $\begin{array}{c}0.163 \\
(0.041) \\
\end{array}$ & $\begin{array}{c}0.313 \\
(0.091) \\
\end{array}$ & $\begin{array}{c}0.357 \\
(0.160) \\
\end{array}$ \\
\hline
\end{tabular}

Note: See table 3. 
Table 4b) Treat zero income/earnings observations as incorrect: Exclude zero income years and use average of log income for remaining years. $\mathrm{N}=142,046$ (incomes); $\mathrm{N}=139,210$ (earnings).

\begin{tabular}{|c|c|c|c|c|c|c|c|c|}
\hline Income: & OLS & $q 25$ & $q 50$ & $q 75$ & $q 90$ & $q 95$ & $q 99$ & q99.9 \\
\hline$\overline{\text { OLS }}$ & $\begin{array}{c}0.251 \\
(0.004)\end{array}$ & & & & & & & \\
\hline Quantile & & $\begin{array}{c}0.208 \\
(0.005) \\
\end{array}$ & $\begin{array}{c}0.218 \\
(0.003) \\
\end{array}$ & $\begin{array}{c}0.256 \\
(0.003) \\
\end{array}$ & $\begin{array}{c}0.279 \\
(0.005) \\
\end{array}$ & $\begin{array}{c}0.267 \\
(0.007)\end{array}$ & $\begin{array}{c}0.268 \\
(0.012) \\
\end{array}$ & $\begin{array}{c}0.312 \\
(0.025) \\
\end{array}$ \\
\hline & $p<25$ & $25<p<50$ & $50<p<75$ & $75<p<90$ & $90<p<95$ & $95<p<99$ & $99<p<99.9$ & $99.9<p$ \\
\hline Spline & $\begin{array}{c}0.119 \\
(0.007)\end{array}$ & $\begin{array}{c}0.506 \\
(0.033)\end{array}$ & $\begin{array}{c}0.292 \\
(0.032)\end{array}$ & $\begin{array}{c}0.433 \\
(0.034)\end{array}$ & $\begin{array}{c}0.200 \\
(0.064)\end{array}$ & $\begin{array}{c}0.121 \\
(0.043)\end{array}$ & $\begin{array}{c}0.398 \\
(0.090)\end{array}$ & $\begin{array}{c}0.919 \\
(0.117)\end{array}$ \\
\hline Earnings & OLS & $q 25$ & $q 50$ & $q 75$ & $q 90$ & $q 95$ & $q 99$ & $q 99.9$ \\
\hline$\overline{\text { OLS }}$ & $\begin{array}{c}0.134 \\
(0.003)\end{array}$ & & & & & & & \\
\hline Quantile & & $\begin{array}{c}0.167 \\
(0.005)\end{array}$ & $\begin{array}{c}0.109 \\
(0.003)\end{array}$ & $\begin{array}{c}0.105 \\
(0.002)\end{array}$ & $\begin{array}{c}0.118 \\
(0.002)\end{array}$ & $\begin{array}{c}0.117 \\
(0.002)\end{array}$ & $\begin{array}{c}0.120 \\
(0.005)\end{array}$ & $\begin{array}{c}0.165 \\
(0.012)\end{array}$ \\
\hline & $p<25$ & $25<p<50$ & $50<p<75$ & $75<p<90$ & $90<p<95$ & $95<p<99$ & $99<p<99.9$ & $99.9<p$ \\
\hline Spline & $\begin{array}{c}0.011 \\
(0.004)\end{array}$ & $\begin{array}{c}0.638 \\
(0.032)\end{array}$ & $\begin{array}{c}0.407 \\
(0.038)\end{array}$ & $\begin{array}{c}0.461 \\
(0.041)\end{array}$ & $\begin{array}{c}0.302 \\
(0.079)\end{array}$ & $\begin{array}{c}0.073 \\
(0.053)\end{array}$ & $\begin{array}{c}0.367 \\
(0.120)\end{array}$ & $\begin{array}{c}0.547 \\
(0.202)\end{array}$ \\
\hline
\end{tabular}

Note: See table 3.

Table 4c) Treat zero income/earnings observations as correct. Use the log of average income for all years treating zeros as just zeros. $\mathrm{N}=142,046$ (incomes); $\mathrm{N}=139,158$ (earnings).

\begin{tabular}{|c|c|c|c|c|c|c|c|c|}
\hline Income: & OLS & $q 25$ & $q 50$ & $q 75$ & $q 90$ & $q 95$ & $q 99$ & $q 99.9$ \\
\hline$\overline{\text { OLS }}$ & $\begin{array}{c}0.269 \\
(0.003)\end{array}$ & & & & & & & \\
\hline Quantile & & $\begin{array}{c}0.208 \\
(0.004)\end{array}$ & $\begin{array}{c}0.227 \\
(0.004)\end{array}$ & $\begin{array}{c}0.271 \\
(0.004)\end{array}$ & $\begin{array}{c}0.289 \\
(0.005)\end{array}$ & $\begin{array}{c}0.278 \\
(0.008)\end{array}$ & $\begin{array}{c}0.275 \\
(0.011)\end{array}$ & $\begin{array}{c}0.324 \\
(0.026)\end{array}$ \\
\hline & $p<25$ & $25<p<50$ & $50<p<75$ & $75<p<90$ & $90<p<95$ & $95<p<99$ & $99<p<99.9$ & $99.9<p$ \\
\hline Spline & $\begin{array}{c}0.099 \\
(0.007)\end{array}$ & $\begin{array}{c}0.512 \\
(0.031)\end{array}$ & $\begin{array}{c}0.373 \\
(0.031)\end{array}$ & $\begin{array}{c}0.471 \\
(0.032)\end{array}$ & $\begin{array}{c}0.303 \\
(0.061)\end{array}$ & $\begin{array}{c}0.169 \\
(0.041)\end{array}$ & $\begin{array}{c}0.605 \\
(0.084)\end{array}$ & $\begin{array}{c}0.690 \\
(0.102)\end{array}$ \\
\hline Earnings & OLS & $q 25$ & $q 50$ & $q 75$ & $q 90$ & $q 95$ & $q 99$ & $q 99.9$ \\
\hline OLS & $\begin{array}{c}0.145 \\
(0.003)\end{array}$ & & & & & & & \\
\hline Quantile & & $\begin{array}{c}0.165 \\
(0.004) \\
\end{array}$ & $\begin{array}{c}0.112 \\
(0.002)\end{array}$ & $\begin{array}{c}0.121 \\
(0.002) \\
\end{array}$ & $\begin{array}{c}0.125 \\
(0.003) \\
\end{array}$ & $\begin{array}{c}0.120 \\
(0.004) \\
\end{array}$ & $\begin{array}{c}0.129 \\
(0.007) \\
\end{array}$ & $\begin{array}{c}0.175 \\
(0.016) \\
\end{array}$ \\
\hline & $p<25$ & $25<p<50$ & $50<p<75$ & $75<p<90$ & $90<p<95$ & $95<p<99$ & $99<p<99.9$ & $99.9<p$ \\
\hline Spline & $\begin{array}{c}0.026 \\
(0.004)\end{array}$ & $\begin{array}{c}0.452 \\
(0.032)\end{array}$ & $\begin{array}{c}0.515 \\
(0.039)\end{array}$ & $\begin{array}{c}0.441 \\
(0.043)\end{array}$ & $\begin{array}{c}0.354 \\
(0.082)\end{array}$ & $\begin{array}{c}0.081 \\
(0.055)\end{array}$ & $\begin{array}{c}0.291 \\
(0.126)\end{array}$ & $\begin{array}{c}0.607 \\
(0.204)\end{array}$ \\
\hline
\end{tabular}

Note: See table 3. 
Table 4d) Treat zero income/earnings observations as incorrect. Use the log of average income for all years treating zeros as just zeros. $\mathrm{N}=142,046$ (incomes); $\mathrm{N}=139,158$ (earnings).

\begin{tabular}{|c|c|c|c|c|c|c|c|c|}
\hline Income: & OLS & $q 25$ & $q 50$ & $q 75$ & $q 90$ & $q 95$ & $q 99$ & $q 99.9$ \\
\hline$\overline{\text { OLS }}$ & $\begin{array}{c}0.287 \\
(0.003)\end{array}$ & & & & & & & \\
\hline Quantile & & $\begin{array}{c}0.213 \\
(0.004)\end{array}$ & $\begin{array}{c}0.245 \\
(0.003)\end{array}$ & $\begin{array}{c}0.304 \\
(0.004)\end{array}$ & $\begin{array}{c}0.334 \\
(0.004)\end{array}$ & $\begin{array}{c}0.342 \\
(0.007)\end{array}$ & $\begin{array}{c}0.379 \\
(0.018)\end{array}$ & $\begin{array}{c}0.422 \\
(0.022)\end{array}$ \\
\hline & $P<25$ & $25<p<50$ & $50<p<75$ & $75<p<90$ & $90<p<95$ & $95<p<99$ & $99<p<99.9$ & $99.9<p$ \\
\hline Spline & $\begin{array}{c}0.112 \\
(0.007)\end{array}$ & $\begin{array}{c}0.454 \\
(0.029)\end{array}$ & $\begin{array}{c}0.377 \\
(0.027)\end{array}$ & $\begin{array}{c}0.454 \\
(0.029)\end{array}$ & $\begin{array}{c}0.345 \\
(0.055)\end{array}$ & $\begin{array}{c}0.165 \\
(0.036)\end{array}$ & $\begin{array}{c}0.600 \\
(0.074)\end{array}$ & $\begin{array}{c}0.693 \\
(0.085)\end{array}$ \\
\hline Earnings & OLS & $q 25$ & $q 50$ & $q 75$ & $q 90$ & $q 95$ & $q 99$ & $q 99.9$ \\
\hline OLS & $\begin{array}{c}0.185 \\
(0.003)\end{array}$ & & & & & & & \\
\hline Quantile & & $\begin{array}{c}0.194 \\
(0.004) \\
\end{array}$ & $\begin{array}{c}0.158 \\
(0.004) \\
\end{array}$ & $\begin{array}{c}0.171 \\
(0.003) \\
\end{array}$ & $\begin{array}{c}0.174 \\
(0.003) \\
\end{array}$ & $\begin{array}{c}0.162 \\
(0.004) \\
\end{array}$ & $\begin{array}{c}0.176 \\
(0.006) \\
\end{array}$ & $\begin{array}{r}0.218 \\
(0.023) \\
\end{array}$ \\
\hline & $P<25$ & $25<p<50$ & $50<p<75$ & $75<p<90$ & $90<p<95$ & $95<p<99$ & $99<p<99.9$ & $99.9<p$ \\
\hline Spline & $\begin{array}{c}0.041 \\
(0.005) \\
\end{array}$ & $\begin{array}{c}0.513 \\
(0.029) \\
\end{array}$ & $\begin{array}{c}0.420 \\
(0.032) \\
\end{array}$ & $\begin{array}{c}0.446 \\
(0.034) \\
\end{array}$ & $\begin{array}{c}0.350 \\
(0.065) \\
\end{array}$ & $\begin{array}{c}0.098 \\
(0.044) \\
\end{array}$ & $\begin{array}{c}0.314 \\
(0.099) \\
\end{array}$ & $\begin{array}{c}0.535 \\
(0.159) \\
\end{array}$ \\
\hline
\end{tabular}

Note: See table 3. 


\section{Appendix}

Table A1: Structure of attrition.

1. All sons, born in Sweden in 1960-67 and part of the multigenerational register, registered as living in Sweden all years 1996-2005.

2. All sons in 1 and with at least one positive income (earnings) observation.

3. All sons in 1 and with 10 positive income (earnings) observations.

4. All sons in 3 with a known biological father.

5 . All sons in 4 with a biological father who was registered in Sweden all years 1974-1979.

6. All sons in 5 with a biological father who has at least one positive income (earnings) observation.

7. All sons in 6 with a biological father who has positive income (earnings)

observations all years 1974-1979.

\begin{tabular}{cc}
\multicolumn{2}{c}{ Number of observations } \\
\hline Income & Earnings \\
\hline 151,148 & 151,148 \\
150,902 & 148,612 \\
142,716 & 126,045 \\
140,710 & 124,379 \\
134,673 & 119,300 \\
134,599 & 118,638 \\
130,047 & 101,635 \\
\hline
\end{tabular}

Table A2: Descriptive statistics for main income and earnings samples, fathers.

\begin{tabular}{|c|c|c|c|c|c|c|c|c|c|c|c|}
\hline Variable & Concept & Mean & S.D. & Min & P25 & P50 & P75 & P90 & P95 & P99 & Max \\
\hline \multirow{2}{*}{ Age in 1974} & Income & 40.6 & 7.3 & 22 & 35 & 40 & 45 & 51 & 54 & 60 & 81 \\
\hline & Earnings & 40.2 & 6.9 & 22 & 35 & 39 & 45 & 50 & 53 & 58 & 76 \\
\hline \multirow{2}{*}{1974} & Income & 247 & 144 & .1 & 181 & 217 & 276 & 373 & 464 & 785 & 9,882 \\
\hline & Earnings & 244 & 129 & .0 & 183 & 219 & 277 & 373 & 460 & 761 & 3,747 \\
\hline \multirow{2}{*}{1975} & Income & 259 & 170 & .8 & 190 & 228 & 290 & 389 & 484 & 805 & 24,512 \\
\hline & Earnings & 257 & 136 & .0 & 193 & 230 & 292 & 389 & 478 & 778 & 7,500 \\
\hline \multirow{2}{*}{1976} & Income & 261 & 154 & .1 & 193 & 232 & 293 & 393 & 486 & 798 & 16,098 \\
\hline & Earnings & 263 & 134 & .0 & 200 & 237 & 298 & 395 & 484 & 780 & 4,654 \\
\hline \multirow{2}{*}{1977} & Income & 255 & 145 & .1 & 189 & 228 & 289 & 387 & 477 & 776 & 13,240 \\
\hline & Earnings & 257 & 132 & .0 & 195 & 232 & 293 & 389 & 475 & 757 & 6,021 \\
\hline \multirow{2}{*}{1978} & Income & 251 & 146 & .3 & 186 & 224 & 284 & 381 & 470 & 765 & 16,715 \\
\hline & Earnings & 257 & 127 & .3 & 193 & 229 & 289 & 384 & 471 & 751 & 5,432 \\
\hline \multirow{2}{*}{1979} & Income & 252 & 140 & .3 & 187 & 226 & 287 & 382 & 471 & 757 & 12,263 \\
\hline & Earnings & 258 & 130 & .3 & 194 & 231 & 292 & 386 & 474 & 747 & 4,573 \\
\hline \multirow{2}{*}{ Ave(74-79) } & Income & 254 & 137 & 3.1 & 189 & 225 & 283 & 380 & 468 & 764 & 13,950 \\
\hline & Earnings & 256 & 124 & 1.4 & 194 & 228 & 287 & 383 & 468 & 748 & 4,467 \\
\hline \multirow{2}{*}{ Ave(ln74-ln79) } & Income & 12.34 & 0.43 & 7.74 & 12.14 & 12.32 & 12.55 & 12.84 & 13.05 & 13.53 & 16.39 \\
\hline & Earnings & 12.32 & 0.56 & 5.70 & 12.16 & 12.33 & 12.56 & 12.85 & 13.05 & 13.51 & 15.24 \\
\hline
\end{tabular}

Note: The income (earnings) sample consists of father-son pairs with positive income (earnings) all years. Incomes and earnings are in thousand 2005 SEK. Observations are 130,047 (incomes) and 101,635 (earnings). 
Table A3: Descriptive statistics for main income and earnings samples, sons.

\begin{tabular}{|c|c|c|c|c|c|c|c|c|c|c|c|}
\hline Variable & Concept & Mean & S.D. & Min & P25 & P50 & P75 & P90 & P95 & P99 & Max \\
\hline \multirow{2}{*}{ Age in 1996} & Income & 32.3 & 2.3 & 29 & 30 & 32 & 34 & 36 & 36 & 36 & 36 \\
\hline & Earnings & 32.3 & 2.3 & 29 & 30 & 32 & 34 & 36 & 36 & 36 & 36 \\
\hline \multirow{2}{*}{1996} & Income & 236 & 201 & .0 & 179 & 223 & 273 & 346 & 411 & 594 & 37,113 \\
\hline & Earnings & 236 & 118 & .0 & 187 & 231 & 281 & 352 & 412 & 569 & 7,158 \\
\hline \multirow{2}{*}{1997} & Income & 252 & 291 & .0 & 187 & 233 & 287 & 371 & 443 & 672 & 56,278 \\
\hline & Earnings & 251 & 134 & .0 & 197 & 241 & 296 & 377 & 443 & 626 & 9,530 \\
\hline \multirow{2}{*}{1998} & Income & 270 & 254 & .0 & 197 & 244 & 304 & 402 & 486 & 759 & 23,801 \\
\hline & Earnings & 271 & 177 & .0 & 209 & 255 & 315 & 409 & 486 & 707 & 22,235 \\
\hline \multirow{2}{*}{1999} & Income & 292 & 415 & .0 & 206 & 255 & 322 & 437 & 539 & 919 & 65,061 \\
\hline & Earnings & 288 & 182 & .0 & 219 & 264 & 331 & 438 & 525 & 789 & 13,271 \\
\hline \multirow{2}{*}{2000} & Income & 329 & 1,328 & .0 & 216 & 267 & 342 & 476 & 594 & 1,125 & 347,553 \\
\hline & Earnings & 310 & 232 & .0 & 228 & 276 & 352 & 474 & 572 & 901 & 27,566 \\
\hline \multirow{2}{*}{2001} & Income & 320 & 532 & .0 & 220 & 272 & 350 & 485 & 600 & 1,037 & 85,931 \\
\hline & Earnings & 323 & 284 & .1 & 234 & 283 & 365 & 495 & 601 & 976 & 29,412 \\
\hline \multirow{2}{*}{2002} & Income & 323 & 464 & .0 & 224 & 277 & 357 & 492 & 606 & 1,029 & 47,842 \\
\hline & Earnings & 327 & 243 & .0 & 237 & 289 & 372 & 503 & 611 & 980 & 26,369 \\
\hline \multirow{2}{*}{2003} & Income & 323 & 407 & .0 & 226 & 280 & 360 & 494 & 611 & 1,035 & 69,290 \\
\hline & Earnings & 328 & 201 & .0 & 239 & 292 & 375 & 505 & 614 & 979 & 9,529 \\
\hline \multirow{2}{*}{2004} & Income & 336 & 491 & .0 & 231 & 288 & 372 & 513 & 641 & 1,115 & 69,843 \\
\hline & Earnings & 337 & 212 & .0 & 244 & 299 & 386 & 522 & 641 & 1,032 & 11,073 \\
\hline \multirow{2}{*}{2005} & Income & 354 & 423 & .0 & 237 & 297 & 388 & 544 & 691 & 1,311 & 45,223 \\
\hline & Earnings & 350 & 229 & .0 & 250 & 308 & 400 & 546 & 676 & 1,099 & 10,802 \\
\hline \multirow{2}{*}{ Ave(96-05) } & Income & 303 & 316 & .2 & 217 & 263 & 333 & 452 & 557 & 936 & 43,346 \\
\hline & Earnings & 302 & 171 & 1.6 & 224 & 271 & 342 & 455 & 544 & 820 & 13,051 \\
\hline \multirow{2}{*}{ Ave $(\ln 96-\ln 06)$} & Income & 12.45 & 0.49 & 3.13 & 12.25 & 12.46 & 12.69 & 12.98 & 13.18 & 13.60 & 17.50 \\
\hline & Earnings & 12.46 & 0.49 & 5.94 & 12.28 & 12.49 & 12.72 & 13.00 & 13.17 & 13.56 & 16.10 \\
\hline
\end{tabular}

Note: See table 1. 